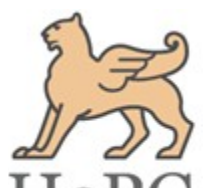

\title{
Plagiochila sisparensis Steph. - a vulnerable liverwort from Nilgiri Hills, Western Ghats
}

\author{
Praveen Kumar Verma ${ }^{1}$, Krishna Kumar Rawat ${ }^{2}$ and Afroz Alam ${ }^{3^{*}}$ \\ ${ }^{1}$ Forest Research Institute, New Forest, Dehradun 248006 (Uttarakhand), India \\ ${ }^{2}$ CSIR-National Botanical Research Institute, Rana Pratap Marg, Lucknow (Uttar Pradesh), India \\ ${ }^{3}$ Banasthali University, P.O. Banasthali Vidyapith- 304022 (Rajasthan), India
}

\author{
Article history \\ Received: 11 September 2015 \\ Accepted: 14 September 2015 \\ Published online: 1 October 2015 \\ (c) Verma et al. (2015) \\ Editors \\ Afroz Alam \\ Dipjyoti Chakraborty

\section{Publisher} \\ Horizon e-Publishing Group \\ Corresponding Author \\ Praveen Kumar Verma \\ 品verma bryo@yahoo.co.in
}

\begin{abstract}
Plagiochila sisparensis Steph., an endemic liverwort of Western Ghats - Sri Lanka hot spot, is recently rediscovered from Avalanche in Nilgiri hills (Tamil Nadu), the area is adjacent to its home place. The species was only recorded from India in 1921 from Sispara (Kerala). After more than 90 years gap it has been rediscovered. The species is easily separable from other species of Plagiochila sect. Tayloriae, and characterized by moderately imbricate leaves which are oblong in shape, spinose teeth, mostly restricted to ventral margin of the leaves. Detailed information is given on its morphology and ecology, and a comparison of similar species of the same section is also discussed.
\end{abstract}

Keywords

Bryophyta; Nilgiri Hills; Plagiochilaceae; Plagiochila; Vulnerable species; Western Ghats

Verma, P. K., Rawat, K. K. and Alam, A. 2015. Plagiochila sisparensis Steph. - a vulnerable liverwort from Nilgiri Hills, Western Ghats. Plant Science Today 2(4): 151-153. http://dx.doi.org/10.14719/pst.2015.2.4.147

\section{Introduction}

The Nilgiri hills of Tamil Nadu is a part of Nilgiri Biosphere Reserve (NBR) and is formed by north south hill ranges which rise from coastal plains of peninsular India, with a few isolated peak such as Dodabetta peak $(2667 \mathrm{~m})$ and Mukuruti peak (2554 $\mathrm{m})$. The Nilgiri lies between $10^{\circ} 1^{\prime}-11^{\circ} 47^{\prime}$ latitude and $76^{\circ} 12^{\prime}$ to $77^{\circ} 15^{\prime}$ longitude spreading on an area of about $2549 \mathrm{sq} \mathrm{Km}$. One side of the area touches the Silent valley of Kerala through Sispara pass while other side by Mudumalai National Park of Nilgiri hills and Bandipur Tiger Reserve of Karnataka.

Genus Plagiochila belongs to family Plagiochilaceae of hepaticae (Bryophyta) and is known as one of the most chaotic genus among the liverworts with about 1800 names described so far, from the world, out of which about 480 names were reported from Asia (So and Grolle, 2000). The taxonomic parameters used for species differentiation of genus Plagiochila includes small to robust plants, simple, dichotomous to dendroid branch habit, stem usually differentiated in to thick - walled, 2-3 layered cortical zone and thin walled medullary cells. Leaves are succubus, alternate and usually toothed, rarely entire or very small teeth while leaf insertion is subtransverse to oblique, dorsal margin of leaf usually longly decurrent, rhizoids restricted only on ventral surface, underleaves vestigial, paraphyllia sometimes present, perianth usually campanulate with truncate mouth, asexual reproduction by means of several devices; flagilliferous branches, caducous leaves or by propagule. The Nilgiri Hills of Tamil Nadu is one of the centers of diversification of liverwort taxa including Plagiochila. After critical evaluation it has been found that genus Plagiochila are represented by 16 genuinely species in Nilgiri hills are Plagiochila acuta Steph., P. beddomei Steph., P. duthiana Steph., $P$. elegans Mitt., P. flexuosa Mitt., P. indica Mitt. Ex Steph., P. fruticosa Mitt., P. gracilis Lindenb. \& Gott., 


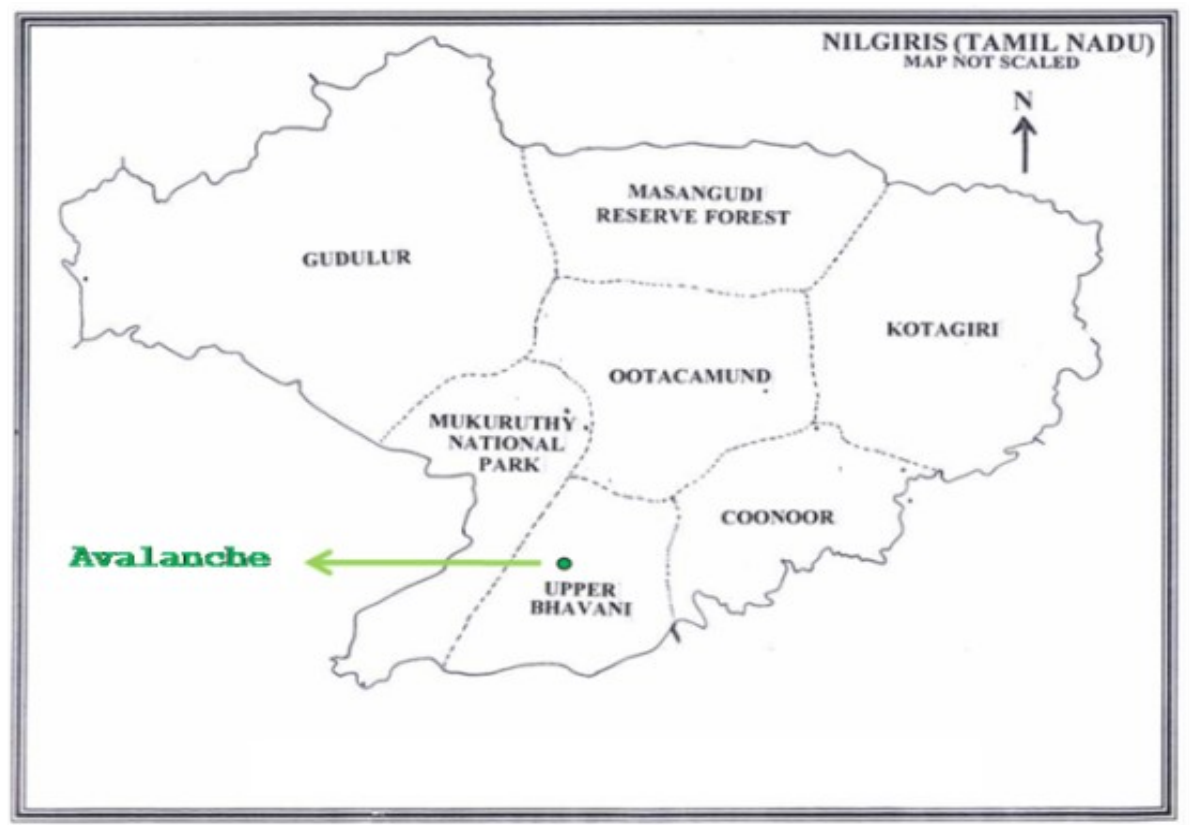

Fig 1. Nilgiris map showing location in Avalanche where the species rediscovered.

$P$. junghuhniana Sande Lac., $P$. nepalensis Lindenb., $P$. peradenyensis Schiffn., $P$. sciophila Nees ex Lindenb., $P$. semidecurrens (Lehm. \& Lindenb.) Lindenb., $P$. sisparensis Steph., $P$. subtropica Steph and $P$. javanica (Swartz) Nees \& Mont. (Srivastava et al., 2007, Srivastava et al., 2002, Srivastava and Verma, 2004; Verma, 2005; Verma and Srivastava, 2008). In which Plagiochila sisparensis is a vulnerable taxa and earlier known from Sispara pass (ca. N 11 ${ }^{\circ} 12^{\prime}$ to $\mathrm{N}$ $11^{\circ} 20^{\prime}$ and $\mathrm{E} 76^{\circ} 25^{\prime}$ to $\mathrm{E} 76^{\circ} 43^{\prime}$ ), juncture of Tamil Nadu and Kerala. After original discovery in 1921 by Stephani, the species was also once documented from Sri Lanka, which is also part of Western Ghats - Sri Lanka Hot spot (Inoue, 1979). However, recently the species rediscovered from Avalanche in Nilgiri Mountains adjacent to Sisapara which receive full force of the southwest monsoon. The species belongs to Plagiochila sect. Tayloriae Carl, with two species in Nilgiri hills, namely $P$. flexuosa Mitt. and $P$. sisparensis St. The area of occupancy is less than $2000 \mathrm{~km}^{2}$ and found in less than ten localities. It therefore meets the IUCN criteria for Vulnerable based on the small area and the decline in habitat quality and extent (Hallingbäck et al., 2000). The species, recently listed by corresponding author himself without any description and illustration (Verma and Srivastava, 2011). A description of species, illustration and threatened category discussed here.

\section{Materials and Methods}

The material for the present study is based on collections from Avalanche in Nilgiris (Fig.1). For the authentication of the species the specimens loaned from Conservatoire et Jardin Botaniques, through the courtesy of the curator. The dry plants were soaked in mild warm water for 2-3 hours for proper stretching of plant specimens to get its natural look (shape). The line drawing was drawn by the corresponding author himself with the help of Camera Lucida.

\section{Observations}

Plagiochila sisparensis Steph., Sp. Hep. 6: 207 (1921). (Fig. 2. a-J; Fig. 3)

Plants in diffused patches, light green, light brown (in herbarium), up to $42 \mathrm{~mm}$ long, 2.5-3.9 mm wide, sparsely branched, dichotomous, branching Frullania-type. Stem 15 cells across the diameter, differentiated, cortical cells 3-4 layered, extremely thick-walled, brown in colour, medullary cells thinwalled, trigones indistinct. Leaves remote, obliquely inserted, horizontally spreading, oblong (oblanceolate), $1.34-1.79 \mathrm{~mm}$ long, 0.82-1.1 mm wide, dorsal margin shortly decurrent, minutely revolute, ventral margin also shortly decurrent, narrowly incurved near the base, dorsal margin almost straight (weakly arched), with 1-2 small, 1-(2) celled teeth on distal half, apex broadly rounded, ventral margin arched, with 2-3 cells long teeth, total teeth 10 (12) in number; apical cells 11-14 × 21-32 $\mu \mathrm{m}$ with indistinct trigones, median cells 14-16 $\times$ 21-32 $\mu \mathrm{m}$ with feebly developed trigones, basal cells large 22-32 × 29-43 $\mu \mathrm{m}$, trigones sub-nodulose. Fertile plant not seen.

Type locality: Nilgiri hills- Sispara (Stephani, 1921). Range: Oriental region: INDIA, Sri Lanka (Stephani, 1921 and Inoue, 1979).

Distribution in India: South India: Kerala (Sispara pass) (see Stephani, 1921); Tamil Nadu - Nilgiri hills [Upper Bhavani (Avalanche)].

Ecology: Plants growing in rough mats on angiospermic trees as corticolous population.

Characteristics of the species: 1 . Plants in diffuse patches, sparsely and dichotomously branched 2 . Leaf oblong-lanceolate 3 . Teeth very small, 1-2 (3) on ventral and apical margins. 


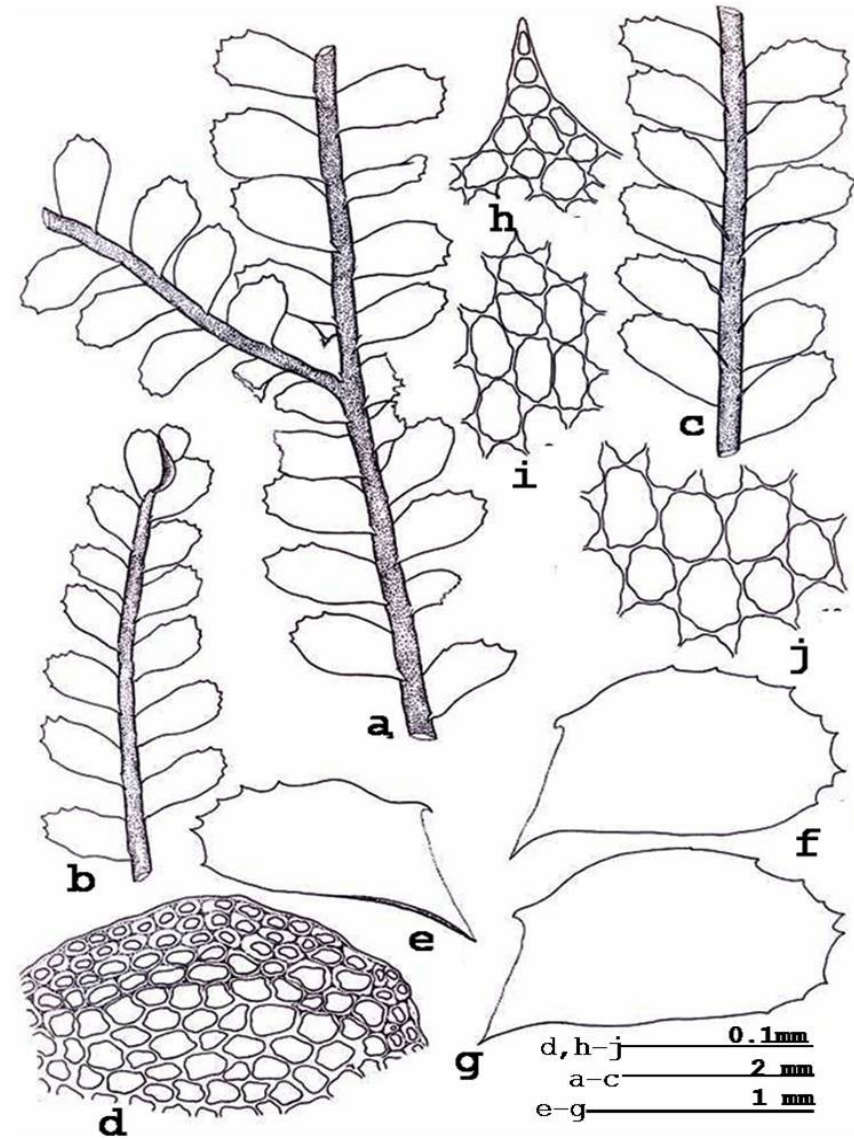

Fig 2. Plagiochila sisparensis Steph. a - j. a \& b - Plant (Dorsal View); c - Plant (Ventral View); $d$ - Cross section of stem, a portion; e - g Leaves; $h$ - Apical cells of leaf; I - Median cells of leaf; $j$ - Basal cells of leaf (All figures drawn from G 10961 except c \& f drawn from LWU 12572/2000).

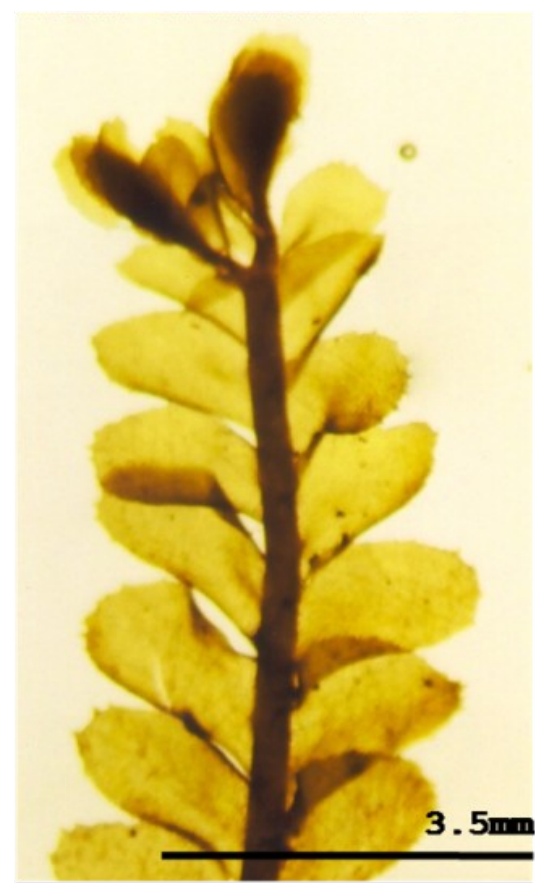

Fig 3. Plagiochila sisparensis Steph., Image taken from LWU $12572 / 2000$
Specimen examined: South India: Tamil Nadu: Nilgiri hills - Sispara; collector unknown; Typus 010961 (G); 09.x.2000; Upper Bhavani (Avalanche); ca. 2200 m, Nilgiri Hills, Tamil Nadu, Western Ghats, S. C. Srivastava an Party, 12572/2000 (LWU).

\section{Result and Discussion}

This species was introduced by Stephani (1921) from Kerala (Sispara). After its original discovery the species was never collected till the present when this species encounter from Avalanche (Nilgiri hills). The plants were found growing in diffused patches. This species was also reported by Inoue (1979) as $P$. pleuridentata Inoue from Sri Lanka which was later synonymzed by So and Grolle (2000) under $P$. sisparensis. This species is placed under Plagiochila sect. Tayloriae and is a close relative of $P$. himalayana of Himalayas, belonging to same section.

Acknowledgements - The authors are grateful to Prof S. C. Srivastava, Ex-Principal Investigator, D.O.E. sponsored AICOPTAX Project and Ministry of Environment and Forestry, New Delhi for financial support under AICOPTAX project to (PKV).

\section{References}

Hallingbäck, T., Hodgetts, N. P. Geissler, and B. C. Tan. 2000. The 2000 IUCN World Red List of Bryophytes http://www.artdata.slu.se/guest/SSCBryo/WorldBryo.htm

Inoue, H. 1979. Contributions to the knowledge of the Plagiochilaceae of southeastern Asia XVIII. A review of the genus Plagiochila (Dum.) Dum. in Ceylon. J Hattori Bot Lab 46: $193-233$.

So, M. L. and R. Grolle. 2000. Checklist of Plagiochila in Asia. J Hattori Bot Lab 88, 199 - 243.

Srivastava S. C., P. K. Verma, and A. Alam. 2007. Plagiochila gracilis Lindenb. \& Gott. and P. subtropica St. in Western Ghats (Nilgiri Hills). Phytotaxonomy 6: 78-83.

Srivastava, S. C. and P. K. Verma. 2004. Exploration of liverwort diversity on Cinchona plantation in Dodabetta, Nilgiri Hills, India. Geophytology 32: 1-18.

Srivastava, S. C., P. K. Verma, and S. A. H. Rizvi. 2002. Plagiochila peradenyensis Schiffn. new to India. Geophytology 30, 75 - 79 .

Stephani, F. 1921. Species Hepaticarum 6: 177-240, Geneve.

Verma P. K and S. C. Srivastava. 2011. Endemism in Liverworts of Western Ghats and their present status. Arch Bryol 99: 1-23

Verma P. K., and S. C. Srivastava. 2008. Plagiochila junghuhniana Sande Lac. new to Indian Mainland (Nilgiri Hills, Western Ghats). J Bombay Nat Hist Soc 105 (2): 236238.

Verma, P. K. 2005. Studies in Hepaticae of Nilgiri hills with special reference to epiphytic taxa. Department of Botany, Lucknow University, Lucknow, xxv +400 pp. 